\title{
Profiling research-capable English teachers throughout Turkey's national teacher education reform history
}

\author{
Ceren Öztabay \\ Girne American University, Faculty of Education, English Language Teaching Department, Girne (Kyrenia), \\ Turkish Republic of Northern Cyprus, cerenoztabay@gau.edu.tr
}

\begin{abstract}
Despite the growing interest in student-teachers' research engagement, little is known about the political significance and representation of research-oriented organization and pedagogies in pre-service English language teacher education (ELTE) programs. Likewise, in Turkey, the predominant scholarly discourse surrounding initial teacher education (ITE) has thus far focused heavily on issues other than the teaching of research knowledge and skills to would-be teachers. This paper attempts to address this gap in knowledge by proposing a preliminary exploration of the officially documented history of I(EL)TE reforms and curriculum development in Turkey through the lens of basic research-oriented teacher education principles. Key outcomes indicate that at the national level, explicit research orientation is underrepresented in the standardized ELTE curriculum and the justifications provided for its integration are nebulous and shallow. Incongruousness between the claims to intensified research-inclusive visions in teacher education and the corresponding manifestation of these in the curricula is a noteworthy conclusion.
\end{abstract}

Keywords English, teacher education, reform, Turkey, curriculum,

\section{Türkiye ulusal öğretmen eğitimi reform tarihi boyunca araştırmada yetkin İngilizce öğretmenlerinin tasvirlenmesi}

ÖZ Öğretmen adaylarının araştırma faaliyetleri konusundaki artan ilgiye rağmen, hizmet öncesi İngilizce dili eğitimi programlarındaki (IDEP) araştırmaya yönelik organizasyon ve pedagojilerin politik önemi ve temsili hakkında çok az şey bilinmektedir. Aynı şekilde, Türkiye'de hizmet öncesi öğretmen eğitimini çevreleyen akademik tartışmalar çoğunlukla öğretmen adaylarına araştırma bilgisi ve becerilerinin kazandırılması dışındaki konularda yoğunlaşmıştır. Bu çalışmada, araştırma odaklı öğretmen eğitiminin temel ilkeleri ışı̆̆ında, resmi olarak belgelenmiş öğretmen eğitimi reformlarının ve takibi müfredat geliştirme geçmişi hakkında bir ön araştırma yapılmış, bahsi geçen bilgi boşluğu irdelenmiştir. Temel bulgular, ulusal düzeyde, sarih araştırma yöneliminin standart İDEP müfredatında yeterince temsil edilmediğini ve entegrasyonu için sunulan gerekçelerin belirsiz ve yüzeysel olduğunu göstermektedir. Öğretmen eğitiminde kapsamlı araştırma yönelimi vizyonunu yansıtan iddialar ile bunların müfredattaki tezahürü arasındaki uyuşmazlık ise çalışmada kayda değer bir vargıdır.

Anahtar

Kelimeler

Ingilizce, ögrretmen ĕgitimi, reform, Türkiye, müfredat,

Cite This

Öztabay, C., (2017). Profiling research-capable English teachers throughout Turkey's

Article: national teacher education reform history, Turkish Journal of Education. 6(3), 96112. DOI: 10.19128/turje.296362 


\section{INTRODUCTION}

Excellence in education is actualized principally by the tireless efforts of 'excellent' teachers. Today, there is an ever-growing scholarly interest in how modern-day teacher excellence is construed and justified globally in view of the peculiarities of local education systems enfolded in their sociopolitical and -economic milieu. Unsurprisingly, international research into teacher education policies concerning prospective teachers' equipment of desirable knowledge and skills has also gained much currency in this regard (Lindsay \& Ginsburg, 1995; McBride, 1996; Furlong, Cochran-Smith \& Brennan, 2009; Earley, Imig \& Michelli, 2011).

The Republic of Turkey is but one of those contexts wherein pre-service (initial) teacher education (TE) historically underwent dramatic reforms in the light of evolving national education visions and missions, especially since the 1980s. It is widely recognized that the EU accession process the country is undergoing has played a particularly key role in the (re)shaping of national education and subsequently, teacher education, in the name of national advancement (Cakiroglu \& Cakiroglu, 2003). Set against the backdrop of 'professionalism', the institutionalization and standardization of teacher education in the country have together been one of the most substantial outcomes of these educational development efforts.

In fact, formal teacher education practices in Turkey are rooted in the 1800s. However, the unification and transfer of the responsibility to the nation's universities dates back to 1982 - a date that also marks the foundation of the Turkish Higher Education Council (HEC) as part of a significant tertiary education reform at the national level. Following a relevant constitutional law passed in 1981, the scattered Turkish higher education system of independent schools, institutes, academies etc. (exclusively governed by the Turkish Ministry of Education, MoE) had been united under the roof of HEC. As part of this transformation, all of the academies were transformed into universities and the previous education institutes, where teacher education had been implemented, were converted into today's Faculties of Education (FoEs). HEC, at present, holds the sole supervisory responsibility toward all of the public and private universities in Turkey as well as North Cyprus. In the purview of this supervision lays the key, centralized protocols of accreditation, standardization and inspection for individual faculties and departments at these institutions. Initial TE programs implemented in FoEs are likewise subject to close-monitoring by HEC. The standards set for these programs include - among several other domains - program structures, length and curricula as well as module proportions, credits and even core descriptions of module content. It is also known that the fulfilment of these requirements plays a particularly critical role in HEC's verdict of approving the launch of any proposed university-based initial teacher education (UBITE) program of studies (Grossman, Sands \& Brittingham, 2010; Yuksel, 2012).

The history of HEC's various main acts and interventions within UBITE is well documented and has long been a matter of heated debate among Turkish scholars (Kucukahmet, 1986; Karagozoglu, 1991; Altan, 1998; Simsek \& Yildirim, 2001; Cakiroglu \& Cakiroglu, 2003; Guven, 2008; Yuksel, 2012; Ozcan, 2013). In this paper, however, the officially documented history of national UBITE will be explored through the lens of basic research-oriented teacher education principles. This has been a remarkably neglected aspect of the possible interpretations of UBITE policy-making in Turkey, especially as far as English language teacher education (ELTE) is concerned. This is particularly important a research area to be recognized and advanced in the context because, as the current paper aims to highlight, research-oriented teaching and teacher education (including ELT(E)), in keeping with the international interest and activity concerning the subject, has been ingrained increasingly in the national education agenda.

\section{LITERATURE REVIEW}

\section{Evidence-Informed Practice and Teacher Research}

Over the past sixty years, the political and practical utility of education research has received considerable critical attention. The existing literature abounds on a polarized opinion on the subject. On the one hand is the assertion that, ideally, all educational inquiry must target direct relevance for and measurable impact on teaching (Hargreaves, 2007). On the other hand, lays the conviction that this vision, 'diagnostic' in nature, is neither plausible nor desirable, given the contexuality and 
complexity of educational activity (Davies, 1999); and also the argued misconception of 'context-free evidence' in education research to supply purely impartial guidelines for practice (Hammersley, 2007). The former outlook on educational inquiry endorses the 'engineering model' for the envisioned corresponding research activity. In this view, the primary function of rigorous educational inquiry is to 'exert a direct influence on educational action in the areas of policy and practice, generating evidence of what works' (Elliot, 2007, p. 67). The latter position, however, does not accept this model of research as the precept of educational inquiry but as a desirable mode, underscoring the significant value of the 'enlightening model' of research in education. As such, the priority set for rigorous educational inquiry is 'to shape the way people think about situations and the problems they raise' (Elliot, 2007, p. 67). Although several well-argued and convincing accounts exist for both ends of the research-practice continuum, common ground seems to have been found as to a shared, fundamental aspiration of enhancing the quality of both of the concerned domains and forging a closer and more productive interlink (i.e. evidence-informed practice/education). Slavin (2002)'s reasoning captures these perceived needs in education concisely. He wrote: 'Education is an applied field. Research in education should ultimately have something to do with improving outcomes for [learners]' (p. 20). Likewise, Cordingley (2004) (among several others) accentuates the potential value of encouraging practitioners in education 'to look at [research] evidence as a means of improving practice and enhancing learning' (p. 83). The field of language teaching in particular has also had its share of debates concerning the most needed and potentially conclusive modes and sources of related research that would maximize learning outcomes. According to some, the future advancement of the enterprise lies in neuro-scientific developments, research on the biology of the human brain and cognition studies (Stapleton, 2014). Whereas others assert that insights from the psychology, linguistics and social sciences research in general must continue to construct awareness and understandings of 'effective' pedagogy in the social and dynamic context of the individual language classroom (Kiely, 2014). At the practitioners' end, in turn, language teachers' conceptions of research and its practical relevance has correspondingly grown in importance as a subject of empirical research (Brindley, 1991; Reis-Jorge, 2007; Borg, 2009; Gao, Barkhuizen \& Chow, 2011; Tabatabaei \& Nazem, 2013).

Indeed, numerous scholars have long been deliberating the possible ways of re-positioning the teachers (and other education practitioners alike) amid these epistemological tensions concerning the argued 'disagreeable' disjunction between educational practice and research. Central to these discussions is the widely renowned idea of what is broadly understood today as 'teacher research', or more inclusively, '(education) practitioner research'. One of the several definitions of the notion reads; 'all forms of practitioner inquiry that involve systematic, intentional, and self-critical inquiry about one's work' (Cochran-Smith \& Lytle, 1999, p. 22). Other compatible conceptualizations also highlight that teacher-initiated inquiry must be systematic and informed by the teacher's own previous or ongoing practice or, at minimum, their own professional context (Freeman, 1998; Borg, 2010). At heart, teacher research aspires to facilitate a fruitful and preferably inartificial interfusion of research activity - in terms of both following/reading published research and undertaking it individually or collaboratively - with the teachers' 'way of working'. It is seen by its proponents as a much needed balancing act in the quest of evidence-informed practice in education by preparing and empowering teachers, alongside researchers and other stake holders, to actively engage with and contribute to the professional discourse, knowledge production and decision-making in the field. In Munthe and Rogne (2015)'s words, advancing the 'scholarship agenda of the teaching profession' (p. 17) is in the purview of enabling research engaged teachers who are not only adept at mediating the complexities of their workplace but also can venture collaborative innovation and positive change in a systematic and accountable manner.

\section{Conceptualizations and Reported Practices}

Unsurprisingly, inspirations from the aforesaid 'research-engaged teacher' visions have had noteworthy repercussion in initial teacher education (ITE) in diverse contexts, commonly in the form of an increased integration of research elements (compulsory or elective) into the program curricula such as research methods/skills courses and 'teacher research' projects/dissertations (van der Linden, Bakx, Ros, Beijaard \& Vermeulen, 2012). However, a review of previous literature suggests that considerably more is known about the latter mode of student-teacher research learning and engagement. Both in language teaching particularly and social sciences generally, views have been 
expressed as to a lack of substantial and cumulative scholarly dialogue concerning the detailed types, objectives, pedagogies and provision of introductory research methods/skills units designed for wouldbe practitioners (Garner, Wagner \& Kawulich, 2009; Borg, 2013). Likewise, in ELT, Nguyen (2013) argued relatively recently that the existing knowledge-based models of teacher education, four of which she scrutinized in her comparative study, must be expanded to represent more explicitly the 'increasing attention to research knowledge and skills as an important part of language teacher professional development' (p. 49). Borg (2003) has proposed the term 'research education' (RE) to conceptualize such provision of methodical instructional processes to pre- and in-service language teachers oriented for building 'the attitudes, knowledge and skills which they require to engage in an informed way with research in the course of their professional lives' (p. 41). For the purposes of this paper, this term is adopted to characterize possible research and research-related pedagogical organization and activity in pre-service (E)LTE as represented and justified at the national policy level.

As mentioned earlier, previous studies have revealed that research education in ITE can be 'teacher research' oriented - that is, delivered as modular units immediately before or at the time of school placements and teaching practice (usually in the final year of studies) so that STs are equipped and aided by the teacher educators to systematically investigate an aspect of their personal teaching experience (Wallace, 1996; Volk, 2009; Trent, 2012). However, a limited number of alternative studies have also shown that not all ST research will be designed for simulating teacher research at the pre-service level (Jones, 2004; van der Linden, 2012; Lombard \& Kloppers, 2015; Öztabay, 2015). Darling-Hammond (2006) used the term 'research inquiries' to categorize these complementary pedagogical activities that enable STs to further engage in research about teaching and education in generic terms but not necessarily their own teaching practice (e.g. 'shadowing' tasks and classroom observations, randomized surveys, small-scale interview studies, stand-alone literature reviews, article critiques, proposal writing exercises etc.) (p. 107). Underpinning these research education efforts is, the author states, a commitment at the program level to help STs to develop the data collection, careful observation, analytical thinking and questioning skills necessary to nourish a critical and reflective outlook towards practice in general - skills deemed crucial for facilitating ideally a life-long disposition of 'adaptive expertise' beginning from the earliest stage of the STs' professional lives. Loughran (2006) similarly argues for the adoption of a 'student teacher as researcher stance' in initial teacher education. He underscores a pressing need for enabling STs to acquire 'a growing understanding of the diversity of approaches to conducting and portraying research' in education (including modes of teacher research) as reflecting 'the diverse possibilities for bridging the theorypractice gap' and novel, personally meaningful ways of 'conceptualizing and articulating professional knowledge and learning' (p. 146). He further argues that through this approach, STs 'may be encouraged to grow beyond the technical and into the independent, autonomous and sophisticated professional pedagogues primed to teach for understanding' (p. 148). Munthe and Rogne (2015) refer to the principal objective of research-oriented ITE as emphasizing inquiry into school practices as well as teaching and learning in general. Aulls and Shore (2008) describe 'inquiry-driven' educational organization whereby activities like research, problem solving, project-based investigations and discovery learning are all 'curricular imperatives' rather than 'optional add-ons' (p. 23). However, Toom, Kynaslahti, Krokfors, Jyrhama, Byman, Stenberg, Maaranen and Kansanen (2010) argue that it is perhaps the inquirer's disposition and mindset towards teaching and professional development that should be prioritized in research-oriented ITE over - but alongside, nevertheless - technical research skills and knowledge. In a similar vein, Borg (2013) questions the extent of authenticity and 'representativeness' (p. 210) of the (teacher-) research projects undertaken as part of already demanding and compartmentalized award-bearing courses. Numerous empirical studies further provide substantial evidence regarding the challenges of implementing student-teacher research during field placements including time-management, feasibility, relevance, rigour, support and cooperation, 'identity' issues and so forth (Goodman, 1991; Wallace, 1996; Ur, 1998; Labaree, 2003; Kotsopoulos, Mueller \& Buzza, 2012; Öztabay, 2015).

Variation in the conceptualizations of research and research-oriented pedagogies in different ITE programs is naturally foreseeable and hence worth scrutiny. However, as empirical research into the political significance and representation of the phenomenon as a whole has received scant attention in the geographical context of this study (Turkey), the foregoing insights into some of the most 
rudimentary modes of research orientation in ITE pedagogies will inform the focused policy and curricular design-related analysis this paper presents. While a variety of definitions of the constructs 'inquiry' and 'research' have been suggested in the relevant literature, for the purposes of the paper, they will be used interchangeably.

\section{Turkey's Pre-Service Teacher Education Reforms}

As mentioned earlier, the majority of existing debates pertaining to university-based initial teacher education (UBITE) in Turkey are situated centrally within the reform history of the enterprise, commenced with the establishment of HEC in 1982 and continued with the major restructuring and minor revising acts in 1997 and 2006 respectively. Multiple 'insider' expositions by program implementers of the 'aftereffect' and accommodation of the 1997 reform movement especially, owing to its gravity, have played a pivotal role in casting the current understanding of UBITE in the country (Kucukahmet, 1986; Karagozoglu, 1991; Altan, 1998; Simsek \& Yildirim, 2001; Cakiroglu \& Cakiroglu, 2003; Guven, 2008; Grossman et al., 2010; Yuksel, 2012; Ozcan, 2013). A full discussion of these accounts lies beyond the scope of this paper. However, Simsek and Yildirim (2001) usefully summarise the key reform areas wherein change was most momentous. According to the authors, the pre-reform 'anomalies' somewhat rectified included the shortage and oversupply of teachers of certain subjects, scarcity of teacher educators specialised in pedagogy and teaching methods, malfunctioning collaborative infrastructure between FoEs, HEC, MoE and schools, inadequate school experience provided for STs and an overreliance on theory input at the expense of practical application. As regards ELT, the year also marks the date when English was introduced to primary schools (Grade 4 rather than the previous Grade 6 onwards) and made a compulsory study subject, increasing the demand for more qualified English teachers in turn (Kirkgoz, 2007).

The 2006 UBITE reform (or so-called modernisation) in Turkey was inspired by the European Union's report titled as the Green Paper on Teacher Education in Europe published in 2000; and was driven with an aim of updating the previously modelled curricula to address those aspects that proved inefficacious or 'too restrictive' in time (Kavcar, 2003). One of the main inspirations taken from the EU countries' TE approach was the vision of an elevated profile for teaching as a profession and teachers as professionals. Correspondingly, a considerable increase in the overall proportion of the 'General Culture' modules in the UBITE curricula was implemented, which, as an objective, aspired to delineate a 'modern', knowledgeable teacher profile, aware of contemporary developments in education and information technologies (Öztabay, 2015). As for the teachers and teacher candidates of English and other languages, this EU-inspired vision brought about a requisite to teach more communicatively and assess more formatively than before (Kirkgoz, 2007). Expectations of accountability concerning professional decision-making and self-development also rose higher (Koksal \& Convery, 2013).

\section{Empirical Work on Research-Oriented Pedagogy in Turkey's Teacher Education}

As the following analysis of the officially documented evolution of the curricular accommodation of UBITE reforms aim to highlight, in harmony with the 'professional teacher' stance taken politically, explicitly intended research education has also had some coverage in the reformed and revised curricula. Despite this, however, a limited number of Turkish authors eclectically voiced opinions concerning an observed, prevalent dearth or marginalisation of research orientation in UBITE pedagogies, including the mode of teacher research simulations. Cakiroglu and Cakiroglu (2003) assert that national UBITE's curriculum content does not reflect sufficiently 'the intellectual movements in the field of education' (p. 260). They further argue that in-service teachers are offered few opportunities, if any, to explore the possible, systematic ways of screening, evaluating and improving their performance. In an interview study with in-service teachers, Balkar (2014) found that the participants perceived the theory-practice connections made during their pre-service education as weak and irrelevant, expressing positive views towards the idea of more research-informed teacher education policies and pedagogies. The author goes on to argue that explicitly intended research education units (e.g. research methods modules) as well as the 'clinically-based' units in the curricula (e.g. Teaching Practice, School Experience) 'should [therefore] be given more importance in teacher education' (p. 28). Similarly, Akyel (2015) reports on a recent effort of running concomitantly two final-year research education units, namely, an innovative teacher research module and the 
standardised practicum module in the ELTE curriculum. Following a qualitative investigation, the author found that the participant STs benefitted from their teacher research experiences in terms of the ability to problematize aspects of their practice in particular and reframe their conceptions of teaching and learning in general. Akyel (2015) posits that the STs illustrated raised awareness of the classroom as a 'site of inquiry to examine' (p. 1) as well as an increased appreciation of research activity as relevant to and important for teachers' performance and professional development. At the level of policy-making, in a recent documentary study of teacher education standards, Koksal and Convery (2013) found that the ability and capacity to reflect on practice with a view of improvement is not covered as a desirable teacher competence by MoE. In a comprehensive proposal report promoted and published by the Turkish Industrialists' and Businessmen's Association's (TÜSİAD) Social Policies Commission, Ozcan (2013) argues, in great detail, how the current four-year-long national UBITE model must be extended and completely reformed to restore the 'respectability' of the teaching profession and practitioners. As part of his proposal, Ozcan (2013) envisions UBITE curricula wherein theory and practice are equated and addressed in tandem. He further suggests that school-based experiences for STs must start from year-one and comprise several activities and assignments which would help them to observe, reflect on, analyse, discuss, inquire into and conduct research on their own and others' practice as well as professional learning experiences.

\section{METHODOLOGY}

\section{Research Design}

The present analysis has a focus on the national four-year-long BA in English Language Teaching degree and its previously documented national curriculum versions. Currently, there are 58 modules in the national, standardised BA in ELT curriculum, which populate three main module categories. These are, namely, Subject Matter (Alan ve Alan Bilgisi), Pedagogical Formation (Meslek Bilgisi) and General Culture (Genel Kültür) categories. The overall distribution of the module categories across the curriculum is 59\%, 22\% and 19\% respectively. In total, 175 hours of study is schemed of which 143 is theoretical (teorik) and 32 is application/practice (uygulama). Some examples for the Subject Matter modules include Linguistics, Language Acquisition, English Literature, Translation Studies, ELT Approaches and Methods, Morphology, Language Skills, Teaching Young Learners, Electives, and so on. The Pedagogical Formation module category consists of such modules as Classroom Management, Assessment and Evaluation, School Experience and Teaching Practice, Education Psychology, Teaching Principles and Techniques, Counselling etc. The modules that populate the General Culture category include Computer Skills, Effective Communication, Community Service, Turkish Education History and Principles of Atatürk, and so forth.

The majority of the BA in ELT modules are 'fixed', meaning that a module becomes available only in the academic term that it is due (either autumn or spring term). Therefore, for example, if a studentteacher fails or withdraws from a given spring term module, they need to await the next spring term to re-take it.

According to HEC's official student portal, 52 universities in Turkey (public and private) currently offer the ELT degree. However, alternative sources specify that the actual number of the ELT courses is over 90 (Mahalingappa \& Polat, 2013, p. 375); albeit this number is less conclusive as it may or may not include postgraduate-level courses (MA and $\mathrm{PhD}$ ). Six other universities in the Turkish Republic of Northern Cyprus - supervised by HEC - also qualify local English teacher candidates utilising the same, core BA curriculum (Öztabay, 2015).

\section{Research Questions}

In exploring the official, historical position of educating research-capable English teachers in Turkey, the paper addresses the following research questions:

(1) What mentions of 'research' are there, if at all, in the Turkish HEC's selected documents about UBITE history and practice?

(2) What are the modules in the initial ELTE programme's national curricula models that are explicitly framed to involve research education?

(3) How have these explicitly intended research education modules evolved in time as reported in the selected HEC documents? 


\section{Dataset and Analysis}

In the current investigation, the dataset comprised three official documents published in Turkish by HEC in 1998 and 2007 (one major and two auxiliary) (see Higher Education Council, 1998; 2007; 2007a). These were accessed from a small archive of formal HEC publications made available for general public on HEC's official website. The selection criterion specified prior to the archive's screening process was for the potential document(s) to be exclusively and explicitly about national teacher education. Only the aforesaid documents met this criterion. Those HEC publications concerning national higher education in general, which formed the majority of the online archive, were hence disregarded by reason of irrelevance.

The selected documents were close-read several times before analysed inductively. Firstly, a keyword analysis was undertaken to identify and highlight all uses of the word 'research' (araştırma) in the three manuscripts (in .pdf format). Secondly, the documents (along with the in-file highlights) were uploaded on the qualitative data management and analysis software, ${ }^{\mathrm{TM} Q S R-N V i v o ~ 10, \text { for refined }}$ thematic analysis (coding). In total, 53 uses of the keyword were identified in the major HEC publication. 12 of these were interpreted and categorised as 'relevant', appropriate for reporting on in this paper. The refinement (or selection) criteria set for the purpose was for the use(s) (in their immediate textual context - i.e. sentence and/or paragraph) to either explicitly state or imply (1) teaching research skills to teachers, (2) teachers' engagement in research and/or (3) teachers' knowledge of research. Those thematic categories eliminated as 'irrelevant' included such notions as 'research staff' and 'staff research' in academia, 'research centres' and the 'research studies' that the national documents cited.

The auxiliary documents were subjected to the same analytical act, with the same analytical priority. In total, nine relevant uses of the keyword were identified in the initial ELTE related document parts. The remainder of the content, which presented information about other local pre-service TE programs (e.g. BA in Pre-school Education), were excluded from the analysis, given the ELT focus of the present study.

The English translations of this final set of document extracts were shared - along with the originals in Turkish - with two (L1) qualified Turkish speaking colleagues for peer-review and discussion.

\section{FINDINGS and DISCUSSION}

\section{What mentions of 'research' are there, if at all, in the Turkish HEC's selected documents about UBITE history and practice?}

As was mentioned earlier, three dates are considered as milestones in the reform history of UBITE in Turkey (1982, 1997 and 2007) and HEC has thus far published one major and two auxiliary official documents (664 pages in total) to provide a detailed history of the reform movements. Table 1 next demonstrates the frequency and context of the relevant appearances of the keyword 'research' identified in HEC's major publication.

Table 1

Relevant Uses of the Keyword 'Research' in HEC's Major Publication

\begin{tabular}{lc}
\hline Context of Use & Number of Appearance \\
\hline Research and development activities (for teachers to engage in more) & 5 \\
Research-based knowledge (to be increased in teachers) & 3 \\
Education research (to improve UBITE) & 2 \\
Classroom-based education research (to improve UBITE) & 1 \\
Research and inquiry (to be increased in UBITE curricula) & 1 \\
\hline
\end{tabular}

These few research educations related extracts identified appeared in the contexts of the two UBITE reforms in Turkey (1997 and 2006), in generic discussions of the reformed national teacher education aims and objectives. Only one reference was made to RE in the context of HEC's near-future agenda for UBITE curricula in particular (i.e. last table item above).

A review of the original and complete extracts, which laid the groundwork of the above categorization, revealed that an official recognition of research originating from real classrooms as having grassroots potential of educational advancement was not secured until the 1997 UBITE reform era. The following extract elucidates one of the key missions of the National Committee of Teacher 
Education (NCTE) appointed at the time to review the pre-reform state of the Turkish UBITE with a vision of safeguarding the viability and efficacy of the then newly animated reform movement. The committee was also entrusted with the sole responsibility to set and have applied national criteria for UBITE as well as develop and deploy 'quality control' mechanisms. At the curriculum level, the committee was given authority to structure the UBITE programmes and their content.

$[\ldots]$ to facilitate the widening of classroom-based educational research regarding the improvement of the quality of teaching and learning in schools (HEC, 2007, p. 49).

Yet another NCTE mission statement, presented next, particularly underscored that the outcomes of such classroom-based research would also be of important relevance and value for the betterment of the UBITE programs and their overall impact.

[...] to render the pre-service teacher education process effective and productive in light of the country's needs and priorities as well as the contemporary developments and research findings in the field (HEC, 2007, p. 49).

In the context of the second UBITE reform (2006) - or so-called modernization movement - a stronger and more explicit justification for educating and having research-capable teachers was established by HEC. As was mentioned previously, this was in view of 'professionalism' in education with inspirations from the initial teacher education systems of the EU member countries.

A significant feature of the new programs is their correspondence to those in the EU countries [aiming at] educating teachers who are not technicians doing what they are told but rather intellectuals who are problem solvers (HEC, 2007, p. 64-65).

This re-positioning of teachers as problem-solving intellectuals seems to have provided the basis for a (fairly) plainly articulated, official stance embracing a research-literate and research-capable teacher profile as a desideratum of forward-looking national education.

$[\ldots]$ the professionalization of teaching as an occupation and moulding of professional teachers with research-based knowledge of teaching and learning. [...] teachers [as] individuals with the ability of professionally transferring research-based knowledge and educational experiences whose legitimacy are evidenced by applied teaching and learning practices (HEC, 2007, p. 87-88).

Therefore, it may be speculated that at the policy-making level, the Turkish UBITE system, at present, subscribes to the 'scholarship agenda of the teaching profession' (Munthe \& Rogne, 2015, p. 17). However, arbitrary and obscure uses of the constructs of acquiring and transferring 'research-based knowledge' into practice (as desirable teacher skills) tend to give the audience of the formal HEC documents the impression of more wishful thinking than precisely envisioned and exemplified solid action in the quest. Firstly, teachers' practices have been observed to be informed, and often obliquely so, by reading and conducting research in a number of possible, complexly interwoven domains, leading to the development of or change in, for instance, propositional (factual, what is), procedural (hands-on experimentation of how to) and constructed knowledge (metacognitive, consciously reflective and criticality-informed) (Reis-Jorge, 2005). Secondly, a recognition is missing entirely as to whether or how research engagement is 'officially' surmised to 'engineer' (impact directly and measurably) and/or 'enlighten' (inform and inspire indirectly) teachers' professional judgement and practice, as has been conceptualised in the relevant literature (Davies, 1999; Elliot, 2007; Hammersley, 2007; Hargreaves, 2007). 'Transfer' (of research-based knowledge), as the word of choice, however, does seem to hint at a possible favouring at the policy-making level of the former view toward educational research and its practical function. Apparently, there is only one available description in the HEC documents of the national UBITE's role in the formal education, methodical preparation and motivation of would-be teachers concerning research activity (see extract below); and this is disappointingly shallow in terms of the nature and/or balance envisioned for pre-service teachers' acquisition, advancement and utilisation of 'research-based knowledge'.

[In the EU report on initial teacher education,] it is suggested for EU member countries' teacher education curricula to incline more towards process, problem, research and inquiry in future (HEC, 2007, p. 90).

As we shall see shortly, nor do the documented UBITE curriculum revision outcomes project a convincing, comprehensive organised act of rendering the programmes more research and inquirydriven than they have conventionally been, as had been claimed on paper. 


\section{What are the modules in the initial ELTE programme's national curricula models that are explicitly framed to involve research education?}

HEC's major publication focuses on the period between 1982 and 2007 in the history of initial TE in Turkey. Therefore, it documents three national curriculum models in total for initial ELTE (as well as other subjects) aligned with the three significant dates - 1982 (establishment of UBITE), 1997 (first UBITE reform) and 2006 (second UBITE reform).

In the first curriculum model presented (1983/84 academic year), no module that was explicitly research education inclusive appeared to be present in the four-year-long ELTE programme's curriculum.

In the second model (1998/99 academic year, post- '97 reform), a new, compulsory module generically titled as Research Skills was introduced with three credits (three lecture hours per week) and to be delivered in the penultimate year of the ELT degree studies (Year 3/Term 2). This aligns with the document extract discussed earlier regarding the up-surged interest toward the potential relevance of educational research outcomes for initial TE in the "97-reform era. Additionally, a second compulsory module titled as Advanced Writing Skills with three credits was placed in Year 2/Term 2, whose content in part involved writing skills for research and thesis work (see Table 2). Whether a finishing thesis/dissertation requirement did in fact exist was not stated explicitly anywhere in the programme and module descriptions. Today, only one UBITE programme (among 14 others), namely, pre-school education, has an explicitly-framed final-year 'research project' requirement (HEC, 2007a, p. 13).

In the final (and latest after the 2006 reform) ELTE curriculum model, the previous Research Skills module was re-titled to become Scientific Research Methods (SRM), albeit with a lowered credit of two. Also, the module was re-located to Year 2/ Term 2 (from Year 3). This reduction of module credits can be interpreted as a rather surprising move given the concurrent, scaled-up HEC plans of developing TE curricula that were 'more research and inquiry-driven'. However, the re-location of the module to the second year of studies may suggest an intention of an earlier introduction to research skills for student-teachers. The Year 2/Term 2 Advanced Writing Skills module was re-titled as Advanced Reading and Writing Skills II (ARaWS II) and hauled down to Year 1/Term 2. The module's credit remained unchanged.

Historically, therefore, two modules in the national curricula versions of the local BA in ELT degree studies have ever proclaimed an explicit role of RE. In harmony with some of the RE practices reported in the previous literature, both modules were compulsory (van der Linden et al., 2012). Among the three curriculum models documented, only the latest specified the module category that each module belonged to (i.e. Subject Matter, Pedagogical Formation and General Culture). While ARaWS II has so far been a Subject Matter module, which envisions only partial and basic research education (Table 2), SRM, which has comprehensive research education at heart, is a General Culture module. The only, relatively rich description below offered by the corresponding auxiliary HEC document illuminates the officially construed role of the General Culture module category as follows.

One of the most important assets of the new programmes is the increased proportion of the general culture modules. The aim of this alteration is to equip the teacher candidate being educated at the university level with the intellectual competence required to exist as a cultured individual. A versatile teacher candidate who has a certain amount of knowledge and capability regarding general culture and information technology and who can conduct scientific research and is able to utilise alreadyconducted research, will be more successful at meeting the requirements of contemporary education. This quality in the teacher will reflect positively on the preparation of the students s/he is educating for future. With this purpose, general culture modules such as $[\ldots]$ scientific research methods $[\ldots]$ have been included in the curricula (HEC, 2007a, p. 8).

It can be inferred from the extract above that a picture of an 'intellectual', research-capable teacher is portrayed for the future of Turkish education. The suggested teacher abilities of both conducting and utilising research are presumed to be of benefit for the teachers' future learners and for a better quality education. Even so, it can also be observed in the above conceptualisation - and the remainder content of the official documents - that how such a benefit would be realised in practice has remained unexplained at the policy-making level. Additionally, the categorisation of research skills development as 'general culture', which, as a module category, is endued with the smallest proportion - and perhaps the highest level of dissimilarity among member modules - in the curriculum, might imply 
that a teacher candidate's knowledge and ability of engaging in/with research is conceptualised as a desirable quality rather than an essential one.

In support of the above interpretation, it is also important to note that these 'general culture' modules are represented in the HEC documents as relatively unstable components of the core UBITE curricula. This representation (below) is besides expressed in such a way that the dispensability of these modules in fact comes across as a virtue of the 'flexible' and hence, commendable, programme structuring.

Within the extent of programme flexibility, (Education) Faculties will be able to implement different general culture modules as well as make changes in these modules in time (HEC, 2007, p. 64).

Owing to the flexible formation of the programmes, Education Faculties will be able to implement different general culture modules and replace the previous ones in time (HEC, 2007a, p. 9).

Paradoxically, however, the very programme structure favourable (in principle) for its underscored flexibility seems to in fact marginalise the already-underrepresented research education practices in the initial ELTE curriculum. Previously, scholars argued for the mainstreaming of RE inclusive modules across all BA-level subjects, including pre-service teacher preparation at universities (Kinkead, 2003; Aulls \& Shore, 2008; Healey \& Jenkins, 2009). Further to that, reflecting on the relevant findings discussed, it seems equally important to consider and re-consider habitually the formal conceptualisation(s), nature and aftereffects of such 'desirable' organised mainstreaming acts regarding RE in UBITE. Doing so will shed additional and valuable light on the official status and hence, potential longevity, conferred on a given RE module (or modules) in a given context and time, even if it has been 'favourably' integrated into curricula.

\section{How have these explicitly intended research education modules evolved in time as reported in the selected HEC documents?}

As was mentioned earlier, the two research education inclusive modules in the latest initial ELTE curriculum underwent modifications regarding their titles and positions in the curriculum. The analysis of HEC's auxiliary documents published in 1998 and 2007 respectively revealed that the modules' content (i.e. brief module descriptions) had also been revised. Table 2 next demonstrates how ARaWS II evolved in time as regards intended objectives.

Table 2

Chronological Development of the National ARaWS II Module

\begin{tabular}{|c|c|}
\hline Module Title and Version & Module Description \\
\hline $\begin{array}{l}\text { Advanced Writing Skills } \\
\text { (Post-1997 UBITE Reform) }\end{array}$ & $\begin{array}{l}\text { Teaching of professional writing skills necessary } \\
\text { for research and thesis writing; Application of } \\
\text { strategies of reviewing, correcting, evaluating and } \\
\text { assessing student compositions (HEC, 1998, p. } \\
61 \text { ). }\end{array}$ \\
\hline $\begin{array}{l}\text { Advanced Reading and } \\
\text { Writing Skills II (Post-2006 } \\
\text { UBITE Reform) }\end{array}$ & $\begin{array}{l}\text { Critical thinking skills, higher order sub-skills of } \\
\text { reading, namely, making inferences and } \\
\text { deductions, reading between the lines, relating } \\
\text { inferences from the text to real life; reacting to } \\
\text { readings; production of different types of essays } \\
\text { (e.g. comparison and contrast, classification, } \\
\text { process analysis, cause-and-effect analysis, and } \\
\text { argumentative); basic research skills including } \\
\text { library/internet search, and basic research report } \\
\text { writing skills such as citing, paraphrasing and } \\
\text { referencing (HEC, 2007a, p. 126). }\end{array}$ \\
\hline
\end{tabular}

In terms of the module's RE-related objectives, a rather dramatic downscaling move strikes from the more advanced professional literacy skills necessary for research and thesis writing to basic information seeking (library and internet search) and research report writing skills. As Badke (2012) argues, an official act of 'dumbing down' the module requirements appear to have been endorsed by HEC (p. 172). He further speculates that an organisational move of this kind is most observable when there exists a strong perception among decision-makers (e.g. tutors, programme administrators, policy makers) of 'failure' in terms of, for example, module methods and/or student interest but perhaps most importantly, when the student-researchers' capability to engage in 'real' research is mistrusted. This 
latter assumption could, to some extent, account for the observed downscaling of ARaWS II's intended research education objectives on paper. Perhaps the pre-2006 UBITE reform goals of introducing first-year STs to real, full-load scholarly thinking, inquiry and writing has in time proved unrealistically ambitious (Goodman, 1991; Wallace, 1996; Ur, 1998; Labaree, 2003; Kotsopoulos et al., 2012; Öztabay, 2015) or simply inessential in actual practice, leading up to the said simplification. It remains difficult, however, to draw a firm conclusion as empirical research into Turkish UBITE policy-making in terms of RE pedagogies is as yet virtually non-existent.

Moving on, Table 3 below demonstrates the revision outcomes of the SRM module's content over time.

Table 3

Chronological Development of the National SRM Module

\begin{tabular}{|c|c|}
\hline Module Title and Version & Module Description \\
\hline $\begin{array}{l}\text { Research Skills (Post-1997 } \\
\text { UBITE Reform) }\end{array}$ & $\begin{array}{l}\text { Teaching of scientific research methods and techniques } \\
\text { and their sampled application; getting students to } \\
\text { conduct small-scale research in their field and its } \\
\text { evaluation (HEC, 1998, p. 63). }\end{array}$ \\
\hline $\begin{array}{l}\text { Scientific Research } \\
\text { Methods (Post-2006 } \\
\text { UBITE Reform) }\end{array}$ & $\begin{array}{l}\text { Science and scientific concepts (fact, knowledge, } \\
\text { absolute, accurate and inaccurate, universal knowledge } \\
\text { etc.); fundamental issues in the history of science; } \\
\text { organisation of scientific research, scientific methods and } \\
\text { different methodological viewpoints; the research } \\
\text { problem, design and sampling methods; data collection } \\
\text { techniques (qualitative and quantitative data gathering); } \\
\text { recording, analysing, interpreting and reporting data } \\
\text { (HEC, 2007a, p. 131). }\end{array}$ \\
\hline
\end{tabular}

Here, contrary to the previous simplification act regarding ARaWS II, a distinct organizational move toward intensifying the SRM module's RE objectives stands out. It appears that the scale was tipped from the conceptual and practical engagement with research methods and techniques (conceptual and applied knowledge plus active fieldwork) to additionally exploring the foundations of field epistemology and methodology (science history, methodological viewpoints, notions of knowledge and truth). As Birbili (2003) reasons, 'discussions of epistemology should be placed in a historical context so students can understand their evolution' (p. 4). Nevertheless, active engagement in the phases and processes of research (from planning to reporting) remained principal in the past and present SRM module versions. Again, one possible reason underlying this move of intensification of RE aims in SRM could be a balancing act with respect to the parallel downscaling of ARaWS II's aims as the only other (supplementary) explicitly-intended RE module in the curriculum. Moreover, perhaps an advanced working knowledge of research paradigms was seen as key in qualifying and enabling the student-teachers to rationally 'argue the link between ontology, epistemology, methodology and method instead of choosing a methodology and fitting everything else around it' (Wagner \& Okeke, 2009, p. 69).

As can also be observed in the foregoing module descriptions, neither AWaRS II nor SRM seems to have ever been tied, on paper, to School Experience or Teaching Practice for the prospect of simulating 'teacher research' (Wallace, 1996; Freeman, 1998; Cochran-Smith \& Lytle, 1999; Volk, 2009; Borg, 2010; Trent, 2012). Therefore, it appears reasonable to imagine that the research projects assigned and completed as part of these modules, if at all, instead resembled 'research inquiries' (Darling-Hammond, 2006; Munthe \& Rogne, 2015), targeting inquiry into aspects of educational practice in general, rather than the student-teachers' own practicum.

\section{CONCLUSION and IMPLICATIONS}

Since the declaration of the republic in the early 1920 s, teacher education has had a prominent role in the educational development agenda of Turkey. In time, valiant and persistent efforts to secularize national education, with a view to strengthening its scientific foundations, have paved the way for the 
centralization and institutionalization of initial teacher education (UBITE) in the country in the early 1980s. The present paper aimed to propose an alternative reading of the formally documented postinstitutionalization reform history of teacher education in the country, with a focus on initial ELTE. Namely, the paper concentrated specifically on the re-represented political understanding(s) of the significance of qualifying research-capable English teacher candidates locally, compliant with the ever-increasing attention to and research on (language) teacher/practitioner research worldwide. These 'official' statements were then complemented and contrasted with a focused analysis of the historical evolution of the standardized ELTE curriculum, considered as a practical, concrete manifestation of UBITE policy intentions in this regard.

The document analysis undertaken identifies a noteworthy incongruence between the projected 'pro' stance taken by stakeholders toward educating research-capable (English) teachers in Turkey and the apparent manifestations of their claimed vision in the national, standardized UBI(EL)TE curricula. It appears that the formally re-represented RE in TE mindset in the context is relatively nascent and narrow. Firstly, it is nascent because even decades after the introduction of (largely implied) RE as a teacher education and professional development aim in the local, re-represented TE policies, explicitly intended and methodical RE appears exceptionally underrepresented in the local (EL)TE curricula (i.e. a single module in a curriculum of 50-plus modules). Secondly, the mindset is narrow because the rearticulated (and sparsely presented) justifications for educating and 'having' (classroom-) research capable and active teachers do not seem to go beyond a generic promulgation of the idea of research, simply as a desirable intellectual activity with grassroots potential of educational change and advancement. The why and how of this formally constructed glorification of teachers' research activity (among other possible quests) were, however, left unexplained at the local (EL)TE policy level. Taken together, these findings suggest a very important role for the Turkish HEC in promoting a stronger and more itemized research education image and ensuring the viability of not only the associated mindset but also the pedagogical implementations.

\section{Implications}

Key implications of this argument for UBITE policy makers and program implementers may include, but are not limited to, first, introducing and integrating explicitly defined, categorized and wellstructured RE pedagogical activities into all modules in all years in an interrelated, progressively more challenging/engaging manner; and second, evaluating the feasibility of introducing clearly framed, meaningful yet realistic hands-on Teacher Research projects into - or alongside - those modules in the curriculum that facilitate school experience and teaching practice opportunities (e.g. reflective inquiry, exploratory practice and action research projects). In this way, it will arguably become more likely that the student-teachers are provided with adequate intellectual 'spaces' to share and discuss (both orally and in writing) their own student-research conceptions and experiences throughout the years, in and outside their classes, with their peers, tutors, the wider campus community and, where relevant, beyond.

Rather recently, it has been voiced that 'nowadays, HEC is planning to reshape pre-service education programs in Turkey' for what would be a third time in the reform history of local UBITE (Akyel, 2015 , p. 12). If so, it will indeed be interesting for those involved with the subject to witness how and when this heralded reform will unfold and whether it will embrace a more explicit and comprehensive research-capable and -active teacher vision mirrored by the updated UBI(EL)TE curricula.

\section{REFERENCES}

Akyel, A. (2015). Research engagement in the EFL pre-service practicum. Language in Focus: International Journal of Studies in Applied Linguistics and ELT, 1, 1-14.

Altan, M. (1998). A call for change and pedagogy: A critical analysis of teacher education in Turkey. European Journal of Education, 33(4), 407-417.

Aulls, M. W., \& Shore, B. M. (2008). Inquiry in education (Volume I): The conceptual foundations for research as a curricular imperative. New York, NY: Lawrence Erlbaum Associates.

Badke, W. B. (2012). Teaching research processes. Oxford, UK: Chandos.

Balkar, B. (2014). Klinik temelli yaklasimin bilgi alanlarini kapsayan arastirma-temelli ogretmen egitimi politikasina iliskin ogretmen algilari. Hacettepe University Journal of Education, 29(4), 28-45. 
Birbili, M. (2003). Teaching educational research methods. Retrieved from http://escalate.ac.uk/resources/teachingresearchmethods/08.html

Borg, S. (2003). Research education as an objective for teacher learning. Retrieved from http://www.education.leeds.ac.uk/assets/files/staff/chapters/Research-education-Borg-2003.pdf

Borg, S. (2009). English language teachers' conceptions of research. Applied Linguistics, 30(3), 358-388.

Borg, S. (2010). Language teacher research engagement. Language Teaching, 43, 391-429.

Borg, S. (2013). Teacher research in language teaching: A critical analysis. Cambridge, UK: CUP.

Brindley, G. (1991). Becoming a researcher: Teacher-conducted research and professional growth. In E. Sadtono (Ed.), Issues in language teacher education (pp. 89-105). Singapore: SEAMEO Regional Language Centre.

Cakiroglu, E. C., \& Cakiroglu, J. C. (2003). Reflections on teacher education in Turkey. European Journal of Teacher Education, 26(2), 253-64.

Cochran-Smith, M., \& Lytle, S. L. (1999). The teacher research movement: A decade later. Educational Researcher, 28(7), 15-25.

Cordingley, P. (2004). Teachers using evidence: Using what we know about teaching and learning to reconceptualise evidence-based practice. In G. Thomas \& R. Pring (Eds.), Evidence-based practice in education (pp. 77-87). Berkshire, UK: Open University Press.

Darling-Hammond, L. (2006). Powerful teacher education: Lessons from exemplary programs. San Francisco, CA: John Wiley and Sons.

Davies, P. (1999). What is evidence-based education? British Journal of Educational Studies, 47(2), 108-121.

Earley, P. M., Imig, D. G., \& Michelli, N. M. (2011). Teacher education policy in the United States: Issues and tensions in an era of evolving expectations. New York, NY: Routledge.

Elliot, J. (2007). Making evidence-based practice educational. In M. Hammersley (Ed.), Educational research and evidence-based practice (pp. 66-88). London, UK: SAGE.

Freeman, D. (1998). Doing teacher research: From inquiry to understanding. London, UK: Heinle \& Heinle.

Furlong, J., Cochran-Smith, M., \& Brennan, M. (2009). Policy and politics in teacher education: International perspectives. London, UK: Routledge.

Gao, X., Barkhuizen, G., \& Chow, A. (2011). "Nowadays, teachers are relatively obedient": Understanding primary school English teachers' conceptions of and drives for research in China. Language Teaching Research, 15(1), 61-81.

Garner, M., Wagner, C., \& Kawulich, B. (2009). Introduction towards a pedagogical culture in research methods. In M. Garner, C. Wagner \& B. Kawulich (Eds.), Teaching research methods in the social sciences (pp. 1-12). Surrey, UK: Ashgate.

Goodman, J. (1991). Using a methods course to promote reflection and inquiry among preservice teachers. In B. R. Tabachnich \& K. Zeichner (Eds.), Issues and practices in inquiry-oriented teacher education (pp. 5676). London, UK: The Falmer Press.

Grossman, G. M., Sands, M. K., \& Brittingham, B. (2010). Teacher education accreditation in Turkey: The creation of a culture of quality. International Journal of Educational Development, 30, 102-109.

Guven, I. (2008). Teacher education reform and international globalization hegemony: Issues and challenges in Turkish teacher education. WASET International Journal of Social, Behavioral, Educational, Economic and Management Engineering, 2(4), 261-270.

Hammersley, M. (2007). Educational research and teaching: A response to David Hargreaves' TTA lecture. In M. Hammersley (Ed.), Educational research and evidence-based practice (pp. 18-42). London, UK: SAGE.

Hargreaves, D. H. (2007). Teaching as a research-based profession: Possibilities and prospects (The teacher training agency lecture 1996). In M. Hammersley (Ed.), Educational research and evidence-based practice (pp. 3-17). London, UK: SAGE.

Healey, M., \& Jenkins, A. (2009). Developing undergraduate research and inquiry. Retrieved from http://www.new1.heacademy.ac.uk/assets/documents/rc_import/developingundergraduate_final.pdf

Higher Education Council. (1998). Ĕgitim fakültesi ögretmen yetiştirme lisans programlarl. Ankara, TR: YÖK.

Higher Education Council. (2007). Öğretmen yetiştirme ve ĕgitim fakülteleri (1982-2007): Öğretmenin üniversitede yetiştirilmesinin değerlendirilmesi. Ankara, TR: YÖK.

Higher Education Council. (2007a). Eğitim fakültesi ögretmen yetiştirme lisans programlart. Ankara, TR: YÖK.

Jones, J. F. (2004). The many benefits of a research component in English language teacher education: A case study. Prospect, 19(2), 25-38.

Karagozoglu, G. (1991). Teacher education reform in Turkey. Action in Teacher Education, 33(3), 26-29.

Kavcar, C. (2003). Cumhuriyet döneminde dal öğretmen yetiştirme. Eğitim Bilimleri Fakültesi Dergisi, 35(1-2), $1-14$.

Kiely, R. (2014). Connecting with teachers: The case for language teaching research in the social sciences. ELT Journal, 68(4), 442-450. 
Kinkead, J. (2003). Learning through inquiry: An overview of undergraduate research. New Directions for Teaching and Learning, 93, 5-17.

Kirkgoz, Y. (2007). English language teaching in Turkey: Policy changes and their implementations. RELC, $38(2), 216-228$.

Koksal, N., \& Convery, A. (2013). Initial teacher education in Turkey and England: Comparing competencies and standards. Journal of Education and Future, 3, 1-20.

Kotsopoulos, D., Mueller, J., \& Buzza, D. (2012). Pre-service teacher research: An early acculturation into a research disposition. Journal of Education for Teaching, 38(1), 21-36.

Kucukahmet, L. (1986). Teacher education in Turkey. European Journal of Teacher Education, 9(1), 33-36.

Labaree, D. F. (2003). The peculiar problems of preparing educational researchers. Educational Researcher, 32(4), 13-22.

Lindsay, B., \& Ginsburg, M. B. (1995). The political dimension in teacher education: Comparative perspectives on policy formation, socialization and society. New York, NY: Falmer.

Lombard, K., \& Kloppers, M. (2015). Undergraduate student teachers' views and experiences of a compulsory course in research methods. South African Journal of Education, 35(1), 1-14.

Loughran, J. (2006). Developing a pedagogy of teacher education: Understanding teaching and learning about teaching. London, UK: Routledge.

Mahalingappa, L. L., \& Polat, N. (2013). English language teacher education in Turkey: Policy vs academic standards. European Journal of Higher Education, 3(4), 371- 383

Markham, W. T. (1991). Research methods in the introductory course: To be or not to be? Teaching Sociology, 19(4), 464-471.

McBride, R. (1996). Teacher education policy: Some issues arising from research and practice. London, UK: Falmer.

Munthe, E., \& Rogne, M. (2015). Research based teacher education. Teaching and Teacher Education, 46, 1724.

Nguyen, M. H. (2013). The curriculum for English language teacher education in Australian and Vietnamese universities. Australian Journal of Teacher Education, 38(11), 33-53.

Ozcan, M. (2013). Okulda universite: Turkiye'de ogretmen egitimini yeniden yapilandirmak icin bir model onerisi. Istanbul, TR: TUSIAD.

Oztabay, C. (2015). The formally stated, observed and perceived realities of research education in initial, university-based English language teacher education in North Cyprus: A case study. (Unpublished PhD Dissertation). University of Warwick, Coventry, United Kingdom.

Reis-Jorge, J. (2005). Developing teachers' knowledge and skills as researchers: A conceptual framework. AsiaPacific Journal of Teacher Education, 33(3), 303-319.

Reis-Jorge, J. (2007). Teachers' conceptions of teacher-research and self-perceptions as enquiring practitioners-A longitudinal case study. Teaching and Teacher Education, 23, 402-417.

Simsek, H., \& Yildirim, A. (2001). The reform of pre-service teacher education in Turkey. In R. G. Sultana (Ed.), Challenge and change in the Euro-Mediterranean region: Case studies in educational innovation (pp. 411-432). New York, NY: Peter Lang.

Slavin, R. E. (2002). Evidence-based education policies: Transforming educational practice and research. Educational Researcher, 31(7), 15-21.

Stapleton, P. (2014). Language teaching research: Promoting a more interdisciplinary approach. ELT Journal, 68(4), 432-441.

Tabatabaei, O., \& Nazem, Y. (2013). English language teachers' conceptions of research. Theory and Practice in Language Studies, 3(3), 521-532.

Toom, A., Kynaslahti, H., Krokfors, L., Jyrhama, R., Byman, R., Stenberg, K., Maaranen, K., \& Kansanen, P. (2010). Experiences of a research based approach to teacher education: Suggestions for future policies. European Journal of Education, 45(2), 331-344.

Trent, J. (2012). Research engagement as identity construction: Hong Kong preservice teachers' experiences of a compulsory research project. Teacher Development, 16(2), 145-160.

Ur, P. (1998). Action research is not so easy. In K. Head (Ed.), TDTR 3: Teachers develop teachers research (pp. 18-25). Whitstable, UK: IATEFL.

van der Linden, W. (2012). Design-based approach to introducing student teachers in conducting and using research. Eindhoven, NL: Eindhoven University of Technology

van der Linden, W., Bakx, A., Ros, A., Beijaard, D., \& Vermeulen, M. (2012). Student teachers' development of a positive attitude towards research and research knowledge and skills. European Journal of Teacher Education, 35(4), 401-419.

Volk, K. S. (2009). Action research as a sustainable endeavor for teachers: Does initial training lead to further action? Action Research, 8(3), 315-332. 
Wagner, C., \& Okeke, C. (2009). Quantitative or qualitative: Ontological and epistemological choices in research methods curricula. In M. Garner, C. Wagner \& B. Kawulich (Eds.), Teaching research methods in the social sciences (pp. 61-70). Surrey, UK: Ashgate.

Wallace, M. (1996). Structured-reflection: The role of the professional project in training ESL teachers. In D. Freeman \& J. C. Richards (Eds.), Teacher learning in language teaching (pp. 281-94). Cambridge, UK: CUP.

Yuksel, I. (2012). The current developments in teacher education in Turkey on the threshold of European Union. International Journal of Humanities and Social Science, 2(8), 49-56. 


\section{TÜRKÇE GENIŞLETILMIŞ ÖZET}

Günümüzde okul öğretmenlerinin profesyönel kimliklerinin doğal bir uzantısı olarak 'araştırmacı' rolünün de katıştırılması üzerine dünyanın bir çok yerinden, sayısı gün geçtikçe artan, çeşitli araştırmalar mevcuttur. Ancak bu rolün öğretmenler tarafından içtenlikle benimsenebilmesi ve araştırma gayretlerinin hakkı ile yerine getirebilmeleri için lüzum eden hazırlık ve eğitim süreçlerinin vadesi ile güçlüğü düşünüldüğünde, öğretmenlerin yalnızca hizmet sırası değil, hizmet öncesi deneyimlerinin de bu konudaki rolü önem kazanmıştır. Buna rağmen, öğretmen adaylarının, özellikle İngilizce öğretmeni adaylarının, hizmet öncesi kalifikasyon eğitimleri boyunca 'araştırma' adına - var ise - nasıl ve ne sıklıkla faal olduklarını belgeleyen çalışmaların sayıca çok az olması dikkat çekicidir. Buna ilaveten, hizmet öncesi (İngilizce) öğretmen eğitiminde araştırma faaliyetlerini kağıt üzerinde dahi olsa öngören, teşvik eden ve/veya düzenleyen herhangi bir ulusal tüzüğün varlı̆̆ı, var ise sistemli bir şekilde incelenmesi konusunda yapılmış araştırmalar ise yok denecek kadar nadirdir.

Bu çalışmada, Türkiye kontekstinde üniversite merkezli hizmet öncesi öğretmen eğitimini ve reform tarihini resmi olarak belgelemek amacı ile YÖK tarafından hazırlanmış ve yayınlanmış, tarih boyunca ilgili tüzüklerin özetlenip yeniden ifade edildiği dokümanlar analiz edilmiş, 'araştırma eğitimi' (research education) olarak tanımlanan (Borg, 2003), geniş anlamda öğretmen adaylarının araştırma bilgi, beceri ve yönelimini kazanması olarak anlaşılan süreç konusunda açıkça belirtilmiş ve/veya ima yoluyla gönderme yapılmış söylemler aranmıştır. Bunu takiben, İngiliz Dili Eğitimi lisans programları özelinde, dokümanlarda beyan edilmiş, reformlar sonucunda revize edilen tüm müfredat versiyonları incelenmiş, araştırma eğitimini pratik anlamda hayata geçirmek amacı güttügü iddia edilebilecek dersler ve bunların içerikleri irdelenmiştir.

$\mathrm{Bu}$ nicel yaklaşım ışığında, aşağıdaki araştırma sorularına cevaplar aranmıştır:

Türkiye YÖK tarafından üniversite merkezli hizmet öncesi öğretmen eğitiminin tarihi ve uygulanmas1 konusunda yayınlanmış olan seçilmiş dokümanlarda 'araştırma'dan - var ise - nasıl bahsedilmiştir?

Hizmet öncesi İngiliz Dili Eğitimi lisans programının ulusal müfredat modellerinde yer alan ve açık bir ifade ile araştırma eğitimini içermesi öngörülmüş dersler hangileridir?

Seçilmiş YÖK dokümanlarındaki belgeler incelendiğinde araştırma eğitimini amaçladığı anlaşılan derslerin içerikleri öğretmen eğitimi tarihi sürecince nasıl bir gelişim göstermiştir?

Araştırmada veri kaynağı olarak YÖK'ün resmi internet sitesinde bulunan 'yayınlarımız' web bağlantı düğmesi ile erişimi sağlanan veri tabanı kullanılmıştır (http://yok.gov.tr/web/guest/yayinlar-veistatistikler). Burada mevcut 40 civarı YÖK yayınında, araştırmanın amacı gözetilerek, üniversite merkezli öğretmen eğitimi üzerine yazılmış olması özelliği taşıması aranmıştır. Bu kritere uyan üç yayın olduğu tespit edilmiş ve veri kaynağı olarak seçilip, incelenmiştir. $\mathrm{Bu}$ incelemede izlenen nicel prosedürde ilk adım olarak, anahtar kelime olması belirlenen 'research' (araştırma) ve çeşitli anlamdaşlarının (ör. 'investigate', 'examine', 'inquire' vs.) ana metindeki bütün kullanımları saptanmıştır. 53 olarak neticelenen bu ilk anahtar kelime kullanımı sayısı, daha sonra araştırma eğitimi tanımı ve prensipleri ile ilişkilendirilebilecek kullanımların saptanması ve ayırılması ile 12'ye düşmüştür. $\mathrm{Bu} 12$ kullanımın tümü, ana metindeki ve ek dokümanlardaki kontekstleri ile birlikte (cümle veya paragraf), bu araştırmada rapor edilmiş ve yapılmış olan yazın taraması ışığında yorumlanmıştır.

Çalışmanın sonucunda Türkiye ulusal öğretmen eğitimi tarihinde araştırmada yetkin (İngilizce) öğretmenler(i) yetiştirme konusuna kayda değer bir önem verilmediği gözlemlenmiştir. İncelenen ana metinde tespit edilen sınırlı sayıdaki açıklamalar ışığında sınıf temelli eğitim araştırmalarının Türkiye'de 1997'deki öğretmen eğitimi reformu bağlamında ulusal eğitim gündemine getirildiği anlaşılmaktadır. Aynı söylemlerde bu tür araştırmaların yaygınlaştırılmasının okullarda 'daha kaliteli' eğitime zemin hazırlayacağı görüşünden de bahsedilmiştir. Bağlantılı olarak, 'çağdaş' öğretmen ve öğretmen adayı resmi anlayışının 'araştırma temelli bilgiye ulaşabilme', 'araştırma becerisine sahip olma', 'yapılmış araştırmalardan yararlanabilme' ve 'araştırma temelli bilgiyi pratikte uygulama' gibi yetkinlikler ile ilişkilendirildiği ve tanımlandığ 1 da saptanmıştır. Bu iddialara rağmen, ek dokümanların incelenmesi sonucunda, reform tarihi boyunca neredeyse 60 dersten oluşan dört yıllık üniversite merkezli hizmet öncesi öğretmen eğitimi standart program müfredatlarında belirli bir oranda araştırma eğitimi amacı güttüğü iddia edilebilecek yalnızca iki ders (İngilizce Öğretmenliği özelinde Illeri Okuma ve Yazma Becerileri ve Bilimsel Araştırma Metodları) olduğu görülmüştür. Ancak, paradoksal olarak, Markham'a (1991) göre; 'özen, kapsamlı açıklamalar, bolca örnek ve tekrar 
olmaksızın araştırma konusunda fazlaca birşey öğretilmesi mümkün olamaz' (p.468, İngilizce'den çeviri, vurgu eklenmiş). Bu bakış açısıyla, Türkiye öğretmen eğitiminde uzun vadeli ve kapsamlı araştırma/araştırma eğitimi yönelimi vizyonunu yansıtan resmi iddialar ile bunların güncel müfredattaki tezahürü arasında önemli bir uyuşmazlık olduğu çalışma sonucunda elde edilen kayda değer bir vargıdır.

Özetle, Türkiye öğretmen eğitiminin, alanında uzman sayısız eğitmen ve araştırmacı tarafınca bilimsel olarak desteklenip teşvik edilmekte olan 'araştırma eğitimi' konusunda da ilerleme kaydetmesi için aşağıdaki çıkarımların politika belirleyiciler, üniversite idarecileri ve öğretmen eğitmenleri tarafından değerlendirilmesi ve hayata geçirilmesi azami önem taşımaktadır;

Hizmet öncesi öğretmen eğitimi tüzük ve programlarının halka açık misyon bildirilerinde araştırma eğitimine açıkça, kapsamlıca ve detaylıca yer verilmesi,

Dört yıllık standart öğretmen eğitimi program müfredatları dahilindeki derslerin tamamına araştırma eğitimi yönelimli, zorluğu ve uğraşları öğrenim yılları sürecince dereceli ve sistematik olarak artan pedagojik aktivitelerin entegre edilmesi,

Aynı müfredatlarda özellikle okul deneyimi ve öğretmenlik uygulamalarına olanak tanıyan derslere anlamlı, pratiğe dayalı ve gerçekçi Öğretmen Araştırması projelerinin getirilmesinin uygulanabilirliğinin değerlendirilmesi. 